ORDINES MILITARES

COLLOQUIA TORUNENSIA HISTORICA

Yearbook for the Study of the Military Orders

ISSN (print) 0867-2008 / ISSN (online) 2391-7512

Nicholas Coureas

Cyprus Research Centre

Gladstonos 6

CY-1095 Nicosia

Cyprus

ncoureas@hotmail.com

\title{
A PROCESS OF SECULARIZATION? VENETIAN HOSPITALLERS AND HOSPITALLER ESTATES ON CYPRUS AFTER 1474
}

\author{
KeYwords \\ Military Orders; Late Middle Ages; Hospitaller Order; Cyprus; Venetians; Catalans
}

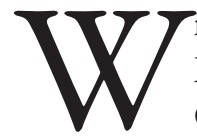

ith the imposition of Venetian control over Cyprus after the death of King James II in July I 473 and the failure of his supporters, mostly Catalans or Sicilians, to seize power from his widow, Queen Catherine Corner, the Hospitallers appointed to the grand commandery of Kolossi, as well as the smaller commanderies of Phoinikas and Templos, were virtually all Venetians who were connected to the new Venetian government of Cyprus. Following Queen Catherine's abdication in 1489 , Venetian control over the Hospitaller Order's Cypriot properties tightened. This article examines why the Venetians wished to have their own nationals appointed to the Cypriot commanderies, to what extent they succeeded and, perhaps most importantly, whether this amounted to secularization or the mere appointing of Venetians to offices in an Order that continued to maintain its clerical character on Cyprus. Also to be discussed are the reactions to this process of appointing Venetian Hospitallers to Cypriot commanderies both on Cyprus and in a wider European context.

Even before the Venetian seizure of control on Cyprus, relations between Venice and the Hospitaller Order of St John had never been harmonious. This observation applies both to Cyprus itself and to the wider European context from the

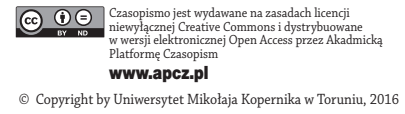


early fourteenth century on. When the Hospitallers had conquered Rhodes from Byzantium in around I 309, they had done so with the help of Venice's arch-rival, Genoa. Although a small number of Venetian merchants was based on fourteenth-century Rhodes, and there was limited trade between Venice and Rhodes, as well as Rhodes and Crete (the largest Venetian possession in the Mediterranean), Venice's Genoese and Catalan rivals benefited far more from their commerce with Hospitaller Rhodes than Venice did. Most of the Order's wealth was located in the West, in France, Spain, and England; thus, the Genoese, Catalans, Provençals, and Florentines traded much more extensively with Rhodes than the Venetians. While Venice and the Hospitallers collaborated in the naval leagues, organized with papal encouragement in the first half of the fourteenth century to combat Turkish piracy in the Aegean, this collaboration was punctuated by quarrels between the Venetians, the Hospitallers, and the Genoese, and open war between Venice and Genoa erupted in 135I. The sack of Alexandria by King Peter I of Cyprus, with Hospitaller assistance, further angered Venice, since it seriously impacted her trade. Hostility continued into the fifteenth century, and in 1403 a Hospitaller ship fought in a Genoese fleet against the Venetians, incurring their anger. At the end of the fifteenth century, the Venetians, according to the Dominican friar Felix Faber, felt no great affection for the Rhodians, for this island was to them a thorn in their eyes and a spear in their sides. ${ }^{1}$

On Cyprus itself, Venice and the Catalans competed for influence under King James II, who had seized the throne from his legitimate half sister Queen Charlotte during the civil war of $1460-1464$, a war in which the Hospitallers officially supported Queen Charlotte, although James was careful not to damage their estates and antagonize them, mindful that he would need papal support to legitimize his rule. James emerged victoriously with the help of Catalan and Sicilian mercenaries, some of whom would obtain high office during his reign, but also married Catherine Corner, a member of one of the most powerful Venetian noble families. George Corner, a grandson of the Venetian Doge Marco Corner (1365-1368) had major economic interests on Cyprus, and Marco, one of his sons, was a major creditor of the Cypriot crown and Catherine's father. Following Catherine's betrothal to King James in July I 468, she became an adopted daughter of Venice, and in October 1469 King James and his kingdom formally came under Venetian protection. The marriage itself did not take place until November I 472 and against the determined Catalan opposition of King Ferrante of Naples, an illegitimate son

1 A. Luttrell, Venice and the Knights Hospitallers of Rhodes in the Fourteenth Century, in: idem, The Hospitallers in Cyprus, Rhodes, Greece and the West 1291-1440, Aldershot 1992, pp. 195-212. 
of King Alfonso $\mathrm{V}$ of Aragon who had acquired the kingdom of Naples and Sicily which Alfonso had conquered from the Angevins in $1442 .{ }^{2}$

After King James II's death in July I 473, Venice soon gained control over Cyprus by offering and sending to the widowed Queen Catherine naval and military support against a plot hatched by the late king's Catalan supporters who, in November I 473, had murdered the queen's uncle, Andrea Corner, George's brother and a royal councillor. Following the arrival of Venetian forces in December I 473 , the leaders of the Catalan party fled Cyprus on board a Neapolitan ship in January 1474. However, opposition to Queen Catherine's establishment of Venetian control over Cyprus also emanated from another quarter, namely from the supporters of Queen Charlotte who, at the time, was residing on Hospitaller Rhodes. Following King James's death, Queen Charlotte sent an envoy to Pietro Mocenigo, the admiral of the Venetian fleet in the eastern Mediterranean, to plead her rights to the kingdom of Cyprus. While expressing sympathy to her plight, Mocenigo made it clear that the possession of kingdoms was based on power, not legal arguments, and that he and the Venetian Republic would defend Queen Catherine's right to rule Cyprus against all opposition. However, Mocenigo was also aware that the Hospitaller squadron attached to the Venetian fleet for operations against the Ottomans had withdrawn once it had become known, after King James's death, that he and his fleet were bound for Cyprus. A plot by Queen Charlotte's Cypriot supporters to seize Kyrenia was foiled on Is August I473, barely a month after King James's death, with the conspirators apprehended and beheaded on 20 August. While the arrival of Venetian troops in December I 473 assured Venetian control, disaffection in favour of Queen Charlotte continued. Thus, when Venice dispatched Queen Catherine's father, Marco Corner, to Cyprus via Rhodes in early 1475 , he was instructed to tell Grand Master Gianbattista Orsini to cease acting against Queen Catherine, for the Order would surely prefer to be the friends and not the enemies of Venice, a scarcely veiled threat. ${ }^{3}$

2 N. Coureas, King James II of Cyprus and the Hospitallers: Evidence from the Livre des Remembrances, in: The Military Orders, vol. 5: Politics and Power, ed. P. Edbury, Farnham 2012, pp. 113-115, 119-121; B. Arbel, A Royal Family in Republican Venice: The Cypriot Legacy of the Corner della Regina, Studii Venetiani, n.s. 15 (1988), pp. 134-138; G. Hill, A History of Cyprus, 4 vols, Cambridge 1940-1952, here vol. 3, pp. 631-642.

3 George Boustronios, A Narrative of the Chronicle of Cyprus 1456-1489, trans. N. Coureas, Nicosia 2005, \$113; Florio Bustron, Chronique de l' ̂̀le de Chypre, ed. R. de Mas Latrie in: Collection des documents inédits sur l'histoire de France: Mélanges historiques, vol. 5, Paris 1886, pp. 434-435; Hill (as n. 2), pp. 599-600, 671-687, 712-713. 
The Catalan Hospitallers on Cyprus embodied the twin Catalan and Hospitaller threats to Venetian control over the island. The Catalan Pedro Raymondo Zacosta was grand master of the Hospitallers in the years I46I-I 467, which spanned the early part of King James's rule, and both under him and his successor, the Italian Grand Master Giovanni Battista degli Orsini ( I 467-1 476), King James cultivated his relations with the Hospitallers posted to Cyprus. Some of these Hospitallers were themselves Catalans or hailed from elsewhere in Spain, such as the brothers Gomez Avila and Nicholas Zaplana. Once Venice had gained control of Cyprus, such brothers, who had relatives among the councillors of the late King James II, had to be neutralized. The fifteenth-century Cypriot chronicler George Boustronios recounts how, on 2 I January I 474, the fiefs and casalia belonging to a certain Brother Gomez, almost certainly the same person as the abovementioned Gomez Avila, were granted to John of Navarre. Gomez Avila may have been related to Peter d'Avila, constable of Cyprus under King James and exiled to Venice in May I 474. Nicholas Zaplana, who had acquired the grand commandery of Kolossi in February I 47 I, had hidden, at Kolossi, the valuables of James Zaplana, governor of the royal treasury under King James and one of the ringleaders of the Catalan party who had been forced to flee Cyprus in January I 474. When visiting Kolossi and interrogating the brothers there, Queen Catherine's Venetian officers discovered this, and, in March I 474, the queen deprived Nicholas Zaplana of the grand commandery, asking the Hospitaller grand master to appoint a replacement. ${ }^{4}$

While Venice exercised the real power behind Queen Catherine Corner's nominal rule, her family wielded considerable influence both in Venice and on Cyprus. This is illustrated by the fact that the future grand commanders of Kolossi, the major Hospitaller commandery on Cyprus, came to be appointed from the Corner family right up to the Ottoman conquest of 1570 . The Hospitaller administration on Rhodes supported the appointment of Venetians to Cypriot commanderies in order to prevent the alienation of the Order's estates on Cyprus and to improve its relations with Venice. On I 3 July I 474, the procurators of the Order's treasury had indeed reported that laymen unconnected to the Order were in control of the grand commandery. On account of this, the Order was receiving no incomes, and therefore Kolossi's Commander Charles de Nores was unable to pay the responsions. In fact, the Order was still seeking the repayment of sums owed by the late King James II, and in March I 475 Charles de Nores was sent to

4 Boustronios (as n. 3), \$\$ 191-192; Coureas, King James II (as n. 2), pp. 115-116; idem, Between Hospitaller Rhodes and Lusignan Cyprus: The Case of the Zaplana Family, Ordines Militares Colloquia Torunensia Historica. Yearbook for the Study of the Military Orders, 19 (2014), pp. 154-155. 
Queen Catherine to secure the repayment of this outstanding debt. ${ }^{5}$ Meanwhile, the Corner family was determined that Venetian control over Kolossi would express itself through their direct control over the grand commandery, which was about to come to pass.

Mark Crispo, the Hospitaller commander of Verona and Queen Catherine's uncle, was appointed to the grand commandery in November I 475. Following his death in 1483 , the French Brother Guy de Blanchefort succeeded him, but at the same time the Venetian Hospitaller Brother Marco Malipiero was appointed administrator in return for an annual payment of 2,400 Venetian ducats. Following Marco's death in January I 508 , the regularity of these payments became the subject of an inquiry, according to instructions issued by Grand Master Emery d'Amboise on 4 November I 5 I 0 . Marco Malipiero had succeeded Guy de Blachefort as grand commander sometime after 27 May I 485, even though the Venetian Senate had asked Queen Catherine to place Malipiero in charge of the grand commandery as early as I 2 January I 484, namely after the Order's grand master had approved his nomination. It was during his tenure that the struggle over the control of the grand commandery took place, one in which the Corner family ultimately prevailed. The first phase of this struggle occurred in 1503 , when Marco attempted to have Kolossi granted to his natural son Andrew as an expectative, only to discover that the grand master had already granted it to Cardinal Marco Corner, George Corner's son and Queen Catherine's nephew. The latter had abdicated in I 489 and was subsequently living in Asolo. Both the pope and the Venetian Council of Ten objected to this grant (the pope at the time being Alexander VI who died in August I 503). Following Marco Malipiero's death on 9 January I 508 , the struggle for the grand commandery extended to Venice itself. Among the city's powerful families coveting the grand commandery, the Grimani stand out, for they persuaded Pope Julius II to grant it to Peter Grimani. ${ }^{6}$

It was at this point that the former queen of Cyprus, Catherine Corner, interceded in favour of her nephew. In a letter dated I 6 January I 508 , addressed to the doge of Venice and the Council of Ten, Catherine extolled her family's services to the Venetian Republic. She then proceeded to state that the grand master simply confirmed candidates nominated by the rulers of Cyprus and that her uncle Marco Malipiero had in this fashion succeeded her uncle Marco Crispo. This was disin-

5 J. Sarnowsky, Macht und Herrschaft im Johanitteorden des 15. Jahrbunderts, Verfassung und Verwaltung der Johanniter auf Rhodos (1421-1522), Münster 2001, pp. 427-428; Hill (as n. 2), p. 698 and note 3 .

6 Sarnowsky (as n. 5), pp. 427-428, 636-637, 672; Venetian Letters from the Archives of the Bank of Cyprus Cultural Foundation and other Cypriot Collections, ed. and trans. B. Arbel, Nicosia 2007, p. 37 and note 43; Arbel (as n. 2), pp. 140-141; Hill (as n. 2), p. 792. 
genuous as it omitted Blanchefort and gave the impression that only Venetians had been appointed to the grand commandery during her reign. Her letter went on to state that, under Pope Alexander VI, this practice had changed to avoid litigation, with the pope nominating and the grand master confirming candidates to the grand commandery. Catherine also claimed that, since Pierre d'Aubusson, the grand master who had granted Kolossi, had died in I 503 , a new confirmation of the grant of Kolossi to Cardinal Marco Corner had been solicited and obtained from the new Grand Master Emery d'Amboise. Catherine also implied that, through the offices of Pope Julius, Peter Grimani had acquired the commandery by unethical means. It was a small part of the kingdom she had acquired and then granted to Venice; meanwhile, Peter was a son of that Anthony Grimani who had been responsible for the Venetians' disastrous defeat by the Ottomans at Sapienza in I 499. While the son could hardly be held responsible for his father's actions, Catherine was clearly contrasting the benefits bestowed upon Venice by the Corner family with the disasters inflicted by the Grimani family. Towards the end of her letter, she stated that she would die of despair should the merits of the Grimani family be considered preferable to those of the Corner family, and further extolled Cardinal Marco's merits. ${ }^{7}$

Despite this letter and the support of the Venetian government, Venice's ambassador declared that the pope wanted Peter Grimani to have the commandery because someone who was not a Hospitaller should not possess a Hospitaller benefice. Yet, Cardinal Marco Corner nonetheless became grand commander and, following his death in July I 524 , was succeeded by his nephew Alvise Corner who was seven years old at the time. The latter was to hold the grand commandery for the next sixty years, becoming a cardinal in I 5 5 I, contributing large sums of money to Venice to enable it to defend Cyprus against the Ottomans, and finally ceding the grand commandery to his brother Federico shortly before his death in 1584 , by which time Cyprus was already an Ottoman province. ${ }^{8}$ Considering that all the Venetians appointed to the office of grand commander on Cyprus were either Hospitallers or cardinals of the Roman Catholic Church, one can argue that, technically speaking, there was no secularization, simply an imposition of Venetian control through the appointment of Venetian Hospitallers to Cypriot commanderies. This was done, moreover, with the Order's acquiescence and papal assent, and as a means to prevent the alienation of the Order's Cypriot posses-

7 Documents nouveaux servant de preuves à l'histoire de l'île de Chypre sous le règne des princes de la maison de Lusignan, ed. L. de Mas Latrie in: Collection des documents inédits: Mélanges historiques, vol. 4, Paris 1882, pp. 572-575.

8 Arbel (as n. 2), p. 141; Hill (as n. 2), pp. 793-794; L. de Mas Latrie, Histoire de l' ̂̀le de Chypre sous le règne des princes de la maison de Lusignan, 3 vols, Paris 1852-1861, here vol. 3, p. 821. 
sions. In this context, one might also point out that the Corner and the Grimani, among the richest pro-papal families in Venice, furnished no less than five of Venice's eight cardinals between I 500 and I 550 , an indication that the rivalry of these two families for ecclesiastical offices was a European phenomenon and not merely confined to Cyprus. ${ }^{9}$

One counter-argument is based on the Venetian grand commanders' actual activities, such as their involvement in trade and the execution of diplomatic missions on behalf of the Venetian state, which made them Hospitallers more in name than in practice. The payment of tithes to the Venetian state from the Cypriot commanderies' revenues, notwithstanding the Order's objections in light of their exemption from such payments confirmed by several popes, forms another argument, this time in favour of the secularization of Hospitaller estates as well as Hospitaller personnel on Cyprus. Turning first to the issue of trade, at least two of the Venetian grand commanders are known to have been involved. One was Marco Crispo, an uncle of Queen Catherine and himself originating from a prominent Venetian family of the Aegean archipelago. On I 6 February i 480, he sent a letter to Nicolo Arimondo, the captain of the galleys dispatched by Venice to Beirut annually for commercial purposes, which the captain received on Rhodes on 5 March I 480 . In this letter, Marco Crispo apologized for not having met the captain, presumably while the latter was stopping off on Cyprus, and sent him ten sugar loaves as a token of goodwill. That Marco Crispo bothered to send such a gift strongly suggests his involvement in the trade between Venice and the Eastern Mediterranean, hence his wish to maintain good relations with the captain of the Beirut galley line. In the case of Marco Malipiero, a subsequent grand commander of the Order on Cyprus, the records for his participation in trade are far clearer. Along with his brothers, he was involved in eastern-Mediterranean trade for many years and lived in the lands under Mamluk rule for long periods of time. Three of his letters, written while he was residing in Pernumia near Padua to look after his sick brother-in-law, shed some light on his commercial activities. ${ }^{10}$

All three letters were addressed to Marino Morosini, probably a business associate. The earliest, dated 8 November 1485 , alluded to the increase in price of Cypriot sugar and cotton due to a drought on the island. Malipiero declared that he wished to receive, on credit from a certain Master Antonio, fixed quantities of sugar, but also of alkali ashes which, as he observed, would now fetch high prices if sent to Tripoli in Syria. In addition, he wished to receive six sacks of cotton for which he would pay cash. He concluded the letter by pointing out that he had

9 J. Ferraro, Venice: History of the Floating City, Cambridge 2012, p. 140.

10 Venetian Letters (as n. 6), pp. 35, 37 and letter no. 8. 
twelve cases of some finely worked Cypriot commodity, perhaps sugar, on board a ship called the Manolessa. With his second letter, dated ig November I 485 , Malipiero instructed Morosini to sell the six sacks of cotton quickly and to use the proceeds to have the sugar released from the customs house in Venice. The third letter, dated 3 December I $_{48}$, is particularly interesting. Malipiero had instructed his nephew Michele to have 40 sacks of cotton and twelve cases of sugar taken out of customs, with a certain Antonio Tron paying for this, because Malipiero did not have the required sum of money. He stated, however, that he had not yet paid for 40 sacks of cotton belonging to Marco Malipiero and Company. This allusion to a commercial firm, possibly his own unless a namesake was involved, shows how deeply Malipiero was engaged in commerce, despite his status as a brother of the Order of St John. It should be pointed out that, on fifteenth-century Rhodes, Hospitaller brothers owned ships which they used for commercial purposes, but where Malipiero perhaps differed from them was in his longstanding involvement in eastern-Mediterranean trade alongside other members of his family. ${ }^{11}$

Marco Malipiero differed from most Hospitallers in another respect as well, namely his involvement in Venetian diplomacy. In April I489, the Venetian government despatched him to Egypt to explain to Sultan Qaitbay the reasons for Queen Catherine's abdication and Venice's direct annexation of Cyprus. On 20 April I 489, he reached Damietta aboard a ship carrying I6,000 Venetian ducats, the bi-annual instalment of the annual tribute payable by Cyprus to the Mamluk sultan from I 426 onwards, when the island had come under Mamluk suzerainty, as well as a gift for the sultan of silks and camlets, the latter being a major Cypriot export throughout the Mediterranean basin. Reaching Cairo on 25 April, he encountered a frosty reception, as the sultan refused to grant him a private audience. While in Egypt, Malipiero also learnt that the sultan had placed Piero de Piero, the Venetian vice-consul at Damietta, under arrest for the latter's role in helping the Venetians capture Rizzo di Marino, one of the leaders of the anti-Venetian party, who had killed Andrea Corner, the queen's uncle, and had fled Cyprus in January I 494. Rizzo had also served as the sultan's envoy to Rhodes, hence the sultan's anger at his capture by the Venetians. Subsequent Venetian embassies were sent to the sultan. That of Pietro Diedo, which reached Cairo in early December, succeeded in its mission by February I 490, but following Diedo's death in late

11 Venetian Letters (as n. 6), pp. 37-38 and letter nos. 11-13; P. Bonneaud, Les Saplana, histoire d'un "clan" familial Catalan et de ses liens avec l'Ordre de l' Hôpital, Societé de l'Histoire et du Patrimoine de l'Ordre de Malte 29 (2013), pp. 44. 
February, Malipiero, still in Cairo, finalized the agreement along with Giovanni Borghi, the late Diedo's secretary. ${ }^{12}$

In the context of secularization, the Hospitaller Order's officers on Cyprus, especially those immediately below the commanders, and their respective powers merit examination. In the early sixteenth century, on both Cyprus and Kos, the administration increasingly came to be exercised by substitutes. One such substitute was James Corner, not a member of the Order but, rather, the secular administrator of the grand commandery of Cyprus, according to a letter addressed to him on behalf of a certain Argyros tou Poli and dated 3 December I 5 1 7. It refers to James Corner as the presente governatore della nostra gran commanderia di Cipro. At the side of these direct subordinates of the grand commander were other officials. Directly below the administrators or governors of the grand commandery were the holders of the officium scribanie generalis magni preceptorie. The holder of this office in October I 495, was John Syncliticos, probably a Greek. From I 507 onwards, John exercised his powers alongside his son Marcos, and in October I 5 I 9 Marcos succeeded him. The administration of the casale of Yermasoyia was attached to his office during this time, although customarily it had been attached to the officium scribanie generalis, and it provided him with supplies. A scribe in Kolossi, the seat of the grand commandery, was also in existence at this time and, around i 5 Io, was appointed by the grand commander. Other appointments or grants made by the grand master himself in the early sixteenth century included the grant of the casalia of Engaddi and Akoursos to Brother Gregory Morgutio, even though they formed part of the grand commandery. The presence of secular and even Greek officials in the positions directly subordinate to the grand commander constitutes evidence for the secularization of the Order's administration on Cyprus..$^{13}$

The Hospitaller estates on Cyprus yielded considerable incomes, which gave the Venetians economic as well as political incentives to control them. How effective they were in doing so, and whether this control amounted to secularization, are the questions now to be addressed. Firstly, the Hospitaller estates on Cyprus, the most valuable estates after those of the crown, numbered 4I villages. Marino Sanudo the Younger estimated their annual incomes in 1508 at 3,000 ducats; a Venetian report written sometime around the years I 5 IO-I 52 I estimated them at 8,000 ducats; and another report dated i 529 estimated them at 6,000 ducats. The Venetian government wanted the Hospitallers to pay tithes on these incomes, but the latter objected strongly. Since the beginning of the fifteenth century, Popes

12 Ambasciatta Straordinaria al Sultano d'Egitto (1489-90), ed. F. Rossi, Venice 1988, pp. 16-17, 32-52, also doc. nos. 139 and XX (Appendice); Hill (as n. 2), pp. 738-742, 821-824.

13 Sarnowsky (as n. 5), pp. 428-429. 
Martin V (I 4I7-I 43 I) and his successor Eugenius IV (I 43 I-I 447) had exempted the Order from paying tithes. ${ }^{14}$

These exemptions notwithstanding, the Venetians appear to have exacted tithes anyway. A letter dated i 3 February i 509 records complaints that Venetian troops were pillaging villages belonging to the Hospital and that tithes were being imposed despite the exemptions previously granted to the Order. The quantities of wheat, cotton, and sugar were so great that insufficient seed remained for the following year's crop. Furthermore, the Latin bishop of Limassol had obtained a licence to sequestrate lands, livestock, and incomes, with neither legal appeals nor protests being permitted. Perhaps in view of these developments, the grand commander of Cyprus sometime before January i 5 i 7 obtained a papal exemption from paying tithes to the Venetian government. The Venetian rectors protested that the revenues from these tithes were needed for the defence of Cyprus. The dispute was finally resolved on 29 December 1525 by an agreement whereby the Hospitallers agreed to pay Venice I,400 Venetian ducats annually. In return, Venice agreed to waive sums owed to it by Cardinal Marco Corner, the recently deceased grand commander, and to return to the Order any sums already paid in this regard. ${ }^{15}$

Venice also exercised control over exports of agricultural produce from Hospitaller estates on Cyprus. As early as March I 478, the Venetian government granted Grand Master Pierre d'Aubusson permission to export as much grain as corresponded to the value of the annual revenues from the Hospitaller estates on Cyprus, provided this was not to the island's detriment. Sometime before $23 \mathrm{Sep}-$ tember I 506, Grand Master Emery d'Amboise had requested permission from the Venetian government to export 10,000 modia of wheat and another I 0,000 modia of barley from the Order's Cypriot estates in order to meet its needs on Rhodes. In its reply, the Council of Ten instructed the Venetian rectors on Cyprus to allow the grand master or his representative to export 5,000 modia of wheat and 10,000 modia of barley, but to do so only after ensuring that the quantities of grain stipulated by the Council were being sent to Venice, and only as long as the rectors could grant the Order's request without prejudice to the security of Cyprus. Two years earlier, on 7 August I 504, the Council of Ten had granted Zacharia de Garzoni, the commander of the smaller Hospitaller commandery of Phoinikas in the

14 Arbel (as n. 2), p. 141 and note 36; Hill (as n. 2), p. 793 and note 1; Mas Latrie (as n. 8), pp. 502-503.

15 A. Luttrell, Ta stratiotika tagmata, in: Historia tes Kyprou, vol. 4: Mesaionikon Basileion, Henetokratia, ed. Th. Papadopoullos, Nicosia 1995, pp. 754-755; Anekdota engrapha tes kypriakes historias apo to kratiko arkheio tes Venetias, ed. Aik. Aristeidou, 4 vols, Nicosia 1990-2003, here vol. 3, no. 108 (p. 215, no. 4); Hill (as n. 2), p. 793. 
Paphos district, permission to export 3,000 stara of wheat or other types of grain from this commandery, but with Venice as the destination. Zacharia Garzoni, whose father was a procurator of St Mark in Venice, hailed from a noble Venetian family which owned its own bank. Garzoni was granted permission by the Council of Ten to export I, 000 stara of wheat and another $\mathrm{I}, 000$ stara of barley in a document dated Io July I 539 , but with the proviso that the agents hiring a ship for him, since he could not do so himself, were to offer guarantees that the grain would be sent to Venice. Venetian permission to export produce from the Order's estates on Cyprus was on occasion solicited and granted in order to settle sums owed to the Order. According to a document of I 2 September I 5 I3, Cardinal Marco Corner was to repay sums he owed the Hospitallers by exporting 6,000 modia of barley to Rhodes from the revenues of his commandery, the Council of Ten having granted the respective permission. ${ }^{16}$

It transpires from a document dated i i April I 526 that the agreement over the payment of tithes reached in December i 525 was implemented. The document refers to the obligation of the newly appointed Grand Commander Alvise Corner to pay tithes for the years 1524 and I 525 from his commandery's revenues and indicates that this money, as well as a payment due from Walter de Cessi, was destined for the Council's treasury. As the Venetian Republic urgently needed money to arm two small galleys, it had been decided that the required funds would be borrowed from the Council's treasury and taken from the sums to be received from Walter de Cessi and Alvise Corner. Clearly the assertion made by the rectors in January I 517 that the money taken from the tithes was needed to defend Cyprus had a basis in fact. Despite the agreement on paying tithes and its implementation, disputes concerning Cypriot estates continued between the Order and the Venetian government, and in one case it was the latter which was on the defensive. In a letter dated I 0 June I 528 , the syndic, provedittore, and advocate of Venice in the East, John Alvise Navagero, informed the Council of Ten that serfs attached to the former crown lands had approached him and complained that the serfs of the current grand commander of Cyprus and his predecessor George Corner had arrogated land which formed part of the royal estate and on which the serfs who were lodging the complaint had planted vines and had been accustomed to cultivate. Navagero, intending to ascertain the truth of the matter and prevent further disputes, had summoned representatives of the grand commander and the late George Corner, who however recused themselves as being unauthorized to deal with this matter and stated that the principals themselves would have

16 Hill (as n. 2), p. 728; Anekdota engrapha (as n. 15), vol. 1, nos. 81, 118; vol. 2, no. 68; vol. 4, no. 139. 
to resolve it. In view of this, Navagero requested the Council of Ten to ask the grand commander and George Corner's heirs to send to their representatives on Cyprus proper written authorization on board the galley line sailing the following September. The resolution of this dispute is not known, but it seems to have concerned instances where Hospitaller estates bordered those of the crown. ${ }^{17}$

Like the grand commandery, the smaller commanderies of Phoinikas in the Paphos district and Templos in the Kyrenia district also witnessed the appointment of Venetian commanders, albeit nominated by the Hospitaller grand master. According to an undated inventory of incomes drawn up by the Venetian administrators in the sixteenth century, the commandery of Phoinikas, consisting of five villages, yielded an annual income of $\mathrm{I}, 600$ Venetian ducats, while that of Templos, a single village, yielded 200 ducats. On 17 May I 483 , following the death of Bartholomew Vendramin, the queen and her councillors on Cyprus were asked to grant the commandery of Phoinikas to Angelo de Malavoltis. In I 490, it was granted to Queen Catherine's brother George Corner as a reward for his part in persuading Catherine to abdicate, thereby opening the way for the imposition of direct Venetian rule. In March I 500, another Venetian, the abovementioned Zacharia Garzoni, acquired the commandery of Phoinikas and leased it for 13 years in return for an annual payment of 400 ducats. The respective document states that he had to pay the tithes and contributions to the Republic in accordance with the decisions of the Signory, proof that the Venetians were exacting tithes from the Hospitaller estates on Cyprus from at least the year I 500 on and probably earlier. This was stipulated despite Zacharias's protestations that, since he had been nominated by the grand master of Rhodes, he was exempt from such payments as a foreign and not a Venetian proprietor. The tithes payable, amounting to an annual total of 60 ducats, were described as his contribution to the island's defence. ${ }^{18}$

Zacharia Garzoni remained commander of Phoinikas for the next four decades, and the matter of the tithes payable to the Venetian administration was raised again in October I 539. The respective document states that, according to a decision taken by the Venetian syndics for the East, the commandery of Phoinikas, the annual revenues of which were estimated to be 450 ducats, used to pay tithes of 90 ducats per year. These were now reduced to 32 ducats per year. The documentation also mentions the agricultural products of the commandery, namely wheat, barley, cotton, wine, olives, carobs, beans, lentils, and haricot beans. As seen above, some of these products, wheat and barley in particular, were exported to Venice or Rhodes. Zacharia Garzoni died sometime before 28 December i 549. The Hos-

17 Anekdota engrapha (as n. 15), vol. 3, nos. 108, 117.

18 Documents nouveaux (as n. 7), pp. 562-563; Mas Latrie (as n. 8), vol. 3, pp. 503, 821. 
pitaller Grand Master Philippe Villiers de l'Isle Adam had granted the Phoinikas commandery as an expectative to the Venetian Pietro Giustinian on 26 January I 523 , a few months after the conquest of Rhodes by the Ottomans, and the latter took possession of it at the end of December I $549 .{ }^{19}$

The small Hospitaller commandery of Templos near Kyrenia resembled the other two on Cyprus in having Venetians appointed as commanders in the early period of Venetian rule, although this practice subsequently appears to have fallen into disuse. In I 5 IO, the commander of Templos was Brother Bruto Muzio, the grandson of Muzio Costanzo, admiral of Cyprus under King James II and regent of the kingdom after his death, and the son of Tuzio Costanzo, a companion of Queen Catherine. On 24 December I 548, Grand Master Juan de Omedes nominated the Aragonese knight Francisco Jorella to succeed the late Anthony de Corogna who had resigned as commander of Templos despite holding the commandery's camera centralis from the grand master in 1547 . The Venetian government allowed Francisco to take possession of Templos on 6 June I 549; perhaps it did not object to a non-Venetian as commander due to this commandery's small size and income..$^{20}$

The relations between the Order, the grand commandery on Cyprus, and the serfs attached to its villages became increasingly hostile as the sixteenth century progressed. In I 547, Grand Master Juan de Omedes despatched Brother Antonio Giovanni Turcheta to Cyprus where, for the first time in many years, he would conduct a visitation of the grand commandery and the smaller commanderies of Phoinikas and Templos. Prior to this, Cypriot serfs had come to Malta twice to register complaints against the grand commander. Brother Giovanni was authorized to handle matters pertaining to the incomes, alienations of properties, and protests. He was also empowered to stop the grand commander from making three appointments normally reserved for the grand master. These were the offices of the scrivania generalis of the grand commandery, referred to above, of the treasurer of the Order's Hospice in Nicosia, and of the overseer of the village of Yermasoyia. Whether Brother Giovanni succeeded in his mission is not known, but the serfs' discontent on Cyprus would have international ramifications, as will be discussed below. This incident illustrates that even in the mid-sixteenth century, over 75 years after the imposition of Venetian control and then direct rule on Cyprus, the Order was resisting Venetian initiatives aimed at securing complete control over appointments of the Order's personnel, as well as its properties and incomes. The Order, moreover, continued to receive responsions from its Cypriot prop-

19 Documents nouveaux (as n. 7), p. 563; Luttrell, Stratiotika tagmata (as n. 15), p. 755.

20 Luttrell, Stratiotika Tagmata (as n. 15), p. 755. 
erties well into the Venetian period. Those payable by the grand commander of Cyprus to the Order were reportedly 2,500 ducats in 1557 and 2,520 ducats in $1559 .^{21}$

The complaints launched sometime before I 547 by the Order's Cypriot serfs against the grand commander were to acquire dimensions beyond the narrow confines of Cyprus. One of the serfs who had visited Malta to complain about the increased exactions imposed on the Order's serfs by the grand commander and the Hospitaller knights was a certain Saffiri Costa who also employed the alias Alvise Spaniolo. He had tried, without success, to secure the intervention of Alvise Corner, heir to George Corner, Queen Catherine's brother, and grand commander of Cyprus. In October or November i 547, serfs attached to the Order's estates appointed him to negotiate their enfranchisement from servile status with the Venetian authorities. Clearly disappointed in this endeavour, the serfs then conceived the idea of making representations to the Ottoman sultan. Their reasoning was that the sultan was entitled to intervene as the suzerain of Cyprus since I 5 17, when the Ottomans had conquered the Mamluk sultanate and thus acquired the Cypriot tribute which the Venetians were paying regularly. Another argument they invoked was that, following the Ottoman conquest of Rhodes in I 522, the sultan had also acquired rights over the Hospitaller estates and villages located on Cyprus. ${ }^{22}$

Saffiri Costa journeyed to Istanbul in May I 55 I to present his case as the representative of the Cypriot serfs on the Hospitaller estates subscribing to these views. There, however, he had the misfortune to be arrested by the Ottoman authorities and turned over to the Venetian bailo, Bernardo Navagero, together with the documentation in Greek found in his possession which bore the signatures of the persons supporting his overtures. Placed into custody by Navagero and subjected to interrogation, he attempted to commit suicide with a razor and eventually died as a result of this. Prior to his eventual death, however, he revealed the names of the villages from which the peasants he represented originated. Of the 47 villagers mentioned in the documents, eleven were Greek priests. The same documents list thirteen Cypriot villages owned by the Hospitaller Order, although Costa mentioned 48 such villages in his oral testimony. Following Costa's death, Navagero informed the Council of Ten of this plot against Venetian rule in Cyprus. On 23 July I 55 I, the Council received a proposal to inform the Venetian authorities

21 Luttrell, Stratiotika Tagmata (as n. 15) pp. 755-756.

22 C. Apostolopoulos, Mia apopeira prosengises ton paroikon tes venetokratoumenes Kyprou me ten othomanike autokratoria, in: Praktika tou Tritou Diethnous Kyprologikou Synedriou, 3 vols, Nicosia 2000-2002, here vol. 2, pp. 670-674; E. Skoufari, Cipro Veneziana (1473-1571), Rome 2011, p. 56. 
in Cyprus of this conspiracy so that those involved could be punished, but this proposal was never put into effect, possibly to avoid antagonizing the Cypriot serfs any further. ${ }^{23}$

From the fourteenth century onwards, relations between the Hospitallers and Venice had never been good, neither on Cyprus itself nor in a broader European context. On taking effective control of Cyprus, the Venetians were determined to neutralize the twin threats presented by the Catalans, who supported the late King James II and subsequently King Ferrante of Naples, and the Hospitallers, who supported Queen Charlotte. The Catalan Hospitallers on Cyprus embodied this twin danger, and thus the Venetians promoted the appointment of Venetian Hospitallers as commanders of the Order's commanderies on the island. The grand masters went along with this to not antagonize the Venetians any further and prevent the total alienation of their estates. To some extent both parties succeeded but, as the Venetians took control, conflicts arose among the Venetian nobility over who would govern the lucrative Hospitaller estates. The Corner, a family already powerful in both Venice and Cyprus, prevailed.

The grand master continued to nominate the Hospitaller commanders to the grand commandery of Cyprus, as well as the two smaller commanderies of Phoinikas and Templos. Nonetheless, those Venetians appointed, even if members of the Order or at least of the Roman Catholic clergy, engaged in secular activities, such as trade and diplomacy. Furthermore, their immediate subordinates were seculars or even Greeks. The export of Hospitaller produce to Venice or Rhodes was subject to permission from the Council of Ten in Venice. Therefore, to a large extent, the imposition of Venetian control resulted in secularization, yet not completely. The Hospitaller grand masters continued to nominate the commanders on Cyprus, they continued to draw responsions from the island and to send knights of the Order to look into the condition of the Hospitaller estates there. As for the Cypriot serfs, the unsuccessful appeal to the Ottomans mentioned above shows that for some of them at least the choice between Hospitallers and Venetians was like the choice between a rock and a hard place.

\section{SOURCES AND LiteratuRE}

Abel, Benjamin., edit. and trans. "Venetian Letters from the Archives of the Bank of Cyprus Cultural Foundation and other Cypriot Collections." Nicosia: Bank of Cyprus Cultural Foundation, 2007.

\footnotetext{
23 Apostolopoulos (as n. 22), pp. 670, 672, 674-677, 688-689; Skoufari (as n. 22), p. 56.
} 
Aristeidou, Aik., edit. "Anekdota engrapha tes kypriakes historias apo to kratiko arkheio tes Venetias." 4 vols. Nicosia: Cyprus Research Centre, 1990-2003.

Boustronios, George. "A Narrative of the Chronicle of Cyprus i 45 6- I 489." Translated by Nicholas Coureas. Nicosia: Cyprus Research Centre, 2005.

Bustron, Florio. "Chronique de l' île de Chypre." edited by Rene de Mas Latrie. In Collection des documents inédits sur l'histoire de France: Mélanges historiques. Vol. 5. Paris: Imprimerie nationale, I 886.

Mas Latrie, Luis de., edit. "Documents nouveaux servant de preuves à l'histoire de l' ̂̂le de Chypre sous le règne des princes de la maison de Lusignan." In Collection des documents inédits: Mélanges historiques. Vol. 4. Paris: Imprimerie nationale, 1882.

Rossi, Franco., edit. "Ambasciatta Straordinaria al Sultano d'Egitto ( $1489-90)$." Venice: Il Comitato Editore, 1988.

Apostolopoulos, Chrestos. "Mia apopeira prosengises ton paroikon tes venetokratoumenes Kyprou me ten othomanike autokratoria." In Praktika tou Tritou Diethnous Kyprologikou Synedriou. 3 vols. Nicosia: Society of Cypriot Studies, 2000-2002.

Arbel, Benjamin. "A Royal Family in Republican Venice: The Cypriot Legacy of the Corner della Regina." Studii Venetiani is (1988): I 3 I- I 52.

Bonneaud, Pierre. "Les Saplana, histoire d'un "clan" familial Catalan et de ses liens avec l'Ordre de l' Hôpital." Societé de l'Histoire et du Patrimoine de l'Ordre de Malte $29(2013): 37-49$.

Coureas, Nicholas. "Between Hospitaller Rhodes and Lusignan Cyprus: The Case of the Zaplana Family." Ordines Militares Colloquia Torunensia Historica. Yearbook for the Study of the Military Orders I 9 (20 I 4): I 43- I 56.

Coureas, Nicholas. "King James II of Cyprus and the Hospitallers: Evidence from the Livre des Remembrances." In The Military Orders, edited by Peter Edbury. Vol. 5: Politics and Power, I $13-12$ I. Farnham: Ashgate, 2012.

Ferraro, Joanne. Venice: History of the Floating City. Cambridge: Cambridge University Press, $20 \mathrm{I} 2$.

Hill, George. A History of Cyprus. 4 vols. Cambridge: Cambridge University Press, I 940$-1952$.

Luttrell, Anthony. "Ta stratiotika tagmata." In Historia tes Kyprou, edited by Theodore Papadopoullos. Vol. 4: Mesaionikon Basileion, Henetokratia, 733-758. Nicosia: Archbishop Makarios III Foundation, 1995.

Luttrell, Anthony. "Venice and the Knights Hospitallers of Rhodes in the Fourteenth Century." In The Hospitallers in Cyprus, Rhodes, Greece and the West I29I-I440, edited by Anthony Luttrell, I 95-2 I 2. Aldershot: Variorum Reprints, 1992.

Mas Latrie, Louis de. Histoire de l'île de Chypre sous le régne des princes de la maison de Lusignan. 3 vols. Paris: Imprimerie nationale, I 852 - I 86 I. 
Sarnowsky, Jürgen. Macht und Herrschaft im Johanitterorden des I5. Jahrhunderts, Verfassung und Verwaltung der Johanniter auf Rhodos (I42I-IS22). Münster: LIT Verlag, $200 \mathrm{I}$.

Skoufari, Evangelia. Cipro Veneziana (1473-I57I). Rome: Viella, 20 I I.

\section{ABstract \\ A Process of Secularization? Venetian Hospitallers and Hospitaller Estates in Cyprus after 1474}

In this paper the appointment of Venetian Hospitallers from 1474 onwards to manage the Hospitaller estates on the island of Cyprus will be examined. The main issue to be discussed with regard to their appointment, which coincided with the imposition of Venetian control over Cyprus, is whether this constituted secularization. Under Queen Catherine Corner (1473-1489) Venetian troops garrisoned Cypriot castles and Venetian officers were appointed to oversee the administration, marking a transition to Venetian governance. Non-Venetian Hospitallers and especially Catalans were viewed with suspicion, given the involvement of at least one Catalan Hospitaller in an unsuccessful plot to expel the Venetian in late 1473. Yet it can be argued that technically there was no secularization and that Venetian Hospitallers simply replaced non-Venetian ones. Nevertheless, given the participation of some of these Venetian Hospitallers in Venetian state diplomacy as well as in commerce involving Venice, a case can be made that in practice secularization did take place, despite the nominal assent the Order gave to the appointment of these Venetian Hospitallers.

The appointment of Venetians to manage Hospitaller estates in Cyprus provoked rivalry among powerful Venetian families within Venice. The two families concerned, the Corner and the Grimani, were powerful and pro-papal, providing most of the Venetian cardinal in the period 1500-1550, so this rivalry can be placed in a wider context. Furthermore, the imposition of Venetian taxes on such estates, despite the Order's protests, also constitutes proof of secularization. Even so, the Hospitaller Order did maintain limited influence over appointments in Cyprus and sent members of the Order to the island to examine conditions on its estates, an indication that it did not lose complete control of its Cypriot properties. 